\title{
Comparative analysis of survival between elderly and non-elderly severe sepsis and septic shock resuscitated patients
}

\author{
Análise comparativa da sobrevida de idosos e não idosos com sepse grave \\ ou choque séptico ressuscitados
}

Henrique Palomba ${ }^{1}$, Thiago Domingos Corrêa ${ }^{1}$, Eliézer Silva ${ }^{1}$, Andreia Pardini ${ }^{1}$, Murillo Santucci Cesar de Assuncao ${ }^{1}$

\begin{abstract}
Objective: To compare outcomes between elderly ( $\geq 65$ years old) and non-elderly $(<65$ years old) resuscitated severe sepsis and septic shock patients and determine predictors of death among elderly patients. Methods: Retrospective cohort study including 848 severe sepsis and septic shock patients admitted to the intensive care unit between January 2006 and March 2012. Results: Elderly patients accounted for $62.6 \%(531 / 848)$ and non-elderly patients for $37.4 \%$ (317/848). Elderly patients had a higher APACHE II score [22 (18-28) versus 19 (15-24); $p<0.001]$, compared to non-elderly patients, although the number of organ dysfunctions did not differ between the groups. No significant differences were found in 28-day and in-hospital mortality rates between elderly and non-elderly patients. The length of hospital stay was higher in elderly compared to non-elderly patients admitted with severe sepsis and septic shock [18 (10-41) versus 14 (8-29) days, respectively; $p=0.0001]$. Predictors of death among elderly patients included age, site of diagnosis, APACHE II score, need for mechanical ventilation and vasopressors. Conclusion: In this study population early resuscitation of elderly patients was not associated with increased inhospital mortality. Prospective studies addressing the long-term impact on functional status and quality of life are necessary.
\end{abstract}

Keywords: Aged; Sepsis; Shock, septic; Shock; Resuscitation; Multiple organ failure; Fluid therapy; Vasoconstrictor agents

\section{RESUMO}

Objetivo: Comparar os resultados obtidos com a ressuscitação de idosos ( $\geq 65$ anos) e não idosos ( $<65$ anos) com sepse grave ou choque séptico e determinar os preditores de óbito em pacientes idosos. Métodos: Estudo de coorte retrospectivo com 848 pacientes com sepse grave ou choque séptico admitidos na unidade de terapia intensiva entre janeiro de 2006 e março de 2012. Resultados: Pacientes idosos representaram 62,6\% (531/848) e não idosos 37,4\% (317/848) dos pacientes. Pacientes idosos apresentaram maior escore APACHE II
[22 (18-28) versus 19 (15-24); $p<0,001$ ] em comparação com pacientes não idosos, embora o número de disfunções orgânicas não tenha sido diferente entre os grupos. Não se observaram diferenças significativas na mortalidade hospitalar e em 28 dias entre pacientes idosos e não idosos, embora o tempo de internação hospitalar tenha sido superior nos pacientes idosos, em comparação com não idosos [18 (10-41) versus 14 (8-29) dias, respectivamente; $p=0,0001]$. Foram preditores de óbito entre pacientes idosos a idade, o local do diagnóstico, o escore APACHE II e a necessidade de ventilação mecânica e vasopressores. Conclusão: A ressuscitação de pacientes idosos com sepse grave ou choque séptico não associou-se ao aumento de mortalidade hospitalar. Estudos prospectivos são necessários para avaliação do impacto a longo prazo no estado funcional e qualidade de vida dos pacientes idosos ressuscitados.

Descritores: Idoso; Sepse; Choque séptico; Choque; Ressuscitação; Insuficiência de múltiplos órgãos; Hidratação; Vasoconstritores

\section{INTRODUCTION}

Severe sepsis and septic shock are major reasons for intensive care unit (ICU) admission worldwide and they are associated with high morbidity and mortality rates, despite intense efforts towards early diagnosis and treatment. ${ }^{(1-3)}$

Rivers et al. ${ }^{(4)}$ proposed the concept of early goaldirected therapy for the treatment of severe sepsis and septic shock patients in 2001. This principle has been incorporated in the Surviving Sepsis Campaign International Guidelines for Management of Severe Sepsis and Septic Shock..$^{(5)}$ Accordingly, early identification, broad spectrum antibiotic administration and hemodynamic stabilization have been the cornerstone of severe sepsis and septic shock management. ${ }^{(6)}$

\footnotetext{
'Hospital Israelita Albert Einstein, São Paulo, SP, Brazil.

Corresponding author: Murillo Santucci Cesar de Assuncao - Avenida Albert Einstein, 627/701, 5th floor - Morumbi - Zip code: $05652-900$ - São Paulo, SP, Brazil - Phone: (55 11) 2151-0520

E-mail: murillo.assuncao@einstein.br

Received on: Dec 24, 2014 - Accepted on: May 21, 2015

Conflict of interest: none.

DOI: 10.1590/\$1679-45082015A03313
} 
The number of elderly patients (age $\geq 65$ years old according to the World Health Organization) with severe sepsis and septic shock has been increasing steadily. ${ }^{(7)}$ This population of elderly patients is characterized by an increased prevalence of chronic illness, comorbidities, frailty and functional impairment. ${ }^{(8,9)}$ Nevertheless, while recent evidence has demonstrated that elderly patients submitted to complex therapeutic interventions during hospitalization showed benefits in long-term survival, ${ }^{(10)}$ observational studies have shown that increased age is an independent predictor of death among septic and non-septic patients. ${ }^{(11-13)}$

We postulated that elderly patients with severe sepsis or septic shock resuscitated following the Surviving Sepsis Campaign Guidelines have similar short-term mortality rates when compared to non-elderly patients with severe sepsis or septic shock.

\section{OBJECTIVE}

To perform a retrospective, single-center cohort study to compare the outcomes between elderly ( $\geq 65$ years) and non-elderly ( $<65$ years) severe sepsis and septic shock resuscitated patients and to determine the main predictors of death among elderly patients.

\section{METHODS}

This study was approved and the informed consent waived by the Hospital Israelita Albert Einstein Institutional Review Board (protocol 716,880 and CAAE: 32786114. 1.0000.0071). This study was conducted in a 41-bed medical-surgical ICU of a tertiary care at a private hospital in São Paulo, Brazil.

\section{Patients}

According to the institutional protocol for severe sepsis and septic shock resuscitation, all patients admitted to the emergency department or those in hospital who had been seen by the rapid response team and fulfilled the criteria for severe sepsis and septic shock were admitted to the ICU. All adult patients with severe sepsis or septic shock admitted to the ICU between January 2006 and December 2012 were included in this study. A case manager followed these patients until hospital discharge and their data were recorded.

The criteria for admission to hospital floor, intermediary care and ICU for patients with no diagnosis of severe sepsis and septic shock was based on the clinical judgment of the attending physician. However, severe sepsis and septic shock patients coming from the emergency department, or those who had been screened by the rapid response team were necessarily admitted to the ICU.

\section{Definitions}

The American College of Chest Physicians/Society of Critical Care Medicine definitions were used and sepsis was defined as infection plus two or more systemic inflammatory response syndrome (SIRS) criteria: temperature $>38^{\circ} \mathrm{C}$ or $<36^{\circ} \mathrm{C}$, heart rate $>90 /$ minute, respiratory rate $>20$ /minute or $\mathrm{PaCO}_{2}<32 \mathrm{mmHg}$, white blood cell count $>12,000$ cells $/ \mathrm{mL}$ or $<4,000$ cells $/ \mathrm{mL}$ (or $>10 \%$ band forms). ${ }^{(14)}$ Severe sepsis was defined as sepsis associated with organ dysfunction, including mental status changes, systolic blood pressure $<90 \mathrm{mmHg}$ or mean arterial pressure (MAP) $<65 \mathrm{mmHg}$, serum creatinine $>2.0 \mathrm{mg} / \mathrm{dL}$ or diuresis $<0.5 \mathrm{~mL} / \mathrm{kg} / \mathrm{h}$, total bilirubin $>2.0 \mathrm{mg} / \mathrm{dL}$, platelet count $<100,000$ cells $/ \mathrm{mm}^{3}$, arterial lactate $>1.5$ time the normal value, INR $>1.5$ or TTPa $>60$ seconds and relationship between arterial oxygen partial pressure and fraction of inspired oxygen $\left(\mathrm{PaO}_{2} / \mathrm{FiO}_{2}\right)<300$.

Septic shock was defined as sepsis-induced hypotension (systolic blood pressure $<90 \mathrm{mmHg}$ or mean arterial blood pressure $<65 \mathrm{mmHg}$ or a drop of $>40 \mathrm{mmHg}$ in the absence of another cause of hypotension) despite adequate fluid resuscitation. Elderly patients were defined according to the World Health Organization as those aged $\geq 65$ years.

\section{Early goal-directed therapy}

All patients were resuscitated following the institutional protocol for severe sepsis and septic shock. The onset of treatment was defined as the time of severe sepsis and septic shock diagnosis. Once a patient was diagnosed with severe sepsis or septic shock, the 6-hour resuscitation bundle was initiated. This included blood sampling with measurement of arterial lactate level, collection of blood cultures before antibiotics administration, broadspectrum antibiotics administration within 1 hour of the onset and a fluid load with crystalloids $(20 \mathrm{~mL} / \mathrm{kg})$ or equivalent doses of colloids. ${ }^{(5)}$

The early goal-directed therapy was applied to patients with severe sepsis associated with arterial lactate levels $\geq 4.0 \mathrm{mmol} / \mathrm{L}$ or those who remained hypotensive (systolic blood pressure $<90 \mathrm{mmHg}$ or MAP $<65 \mathrm{mmHg}$ ) despite fluid resuscitation with crystalloids $(20 \mathrm{~mL} / \mathrm{kg})$ or equivalent doses of colloids. After the diagnosis of severe sepsis or septic shock, the following 
therapeutic goals were targeted during the first 6-hours of resuscitation: central venous pressure between 8 and $12 \mathrm{mmHg}$ (12 to $15 \mathrm{mmHg}$ in mechanically ventilated patients), MAP $\geq 65 \mathrm{mmHg}$, central venous oxygen saturation $\left(\mathrm{SvcO}_{2}\right)$ or mixed venous $\left(\mathrm{SvO}_{2}\right) \geq 70 \%$ and $65 \%$, and diuresis $\geq 0.5 \mathrm{~mL} / \mathrm{kg} / \mathrm{h}$.

\section{Variables collected}

Demographic data, number of comorbidities, location before ICU admission, number of new organ dysfunctions at severe sepsis and septic shock diagnosis, source of infection, Acute Physiology and Chronic Health Evaluation II (APACHE) score, ${ }^{(15)}$ need for vasopressors, invasive mechanical ventilation, amount of fluids administered, in-hospital and ICU length of stay, inhospital and mortality at day 28 were collected.

\section{Statistical analysis}

Categorical variables were presented as absolute and relative frequencies. Continuous variables were presented as mean and standard deviation (SD) when normally distributed and as median and interquartile range (IQR) when not normally distributed (tested by the Kolmogorov-Smirnov test).

Patients were divided into two groups according to the age: elderly patients ( $\geq 65$ years) and non-elderly patients ( $<65$ years). Categorical data were compared between elderly and non-elderly patients with the $\chi^{2}$ test or Fisher's exact test when appropriate. Continuous data were compared with the independent $t$ test when normally distributed and with the Mann-Whitney U test in the case of non-normal distribution.

A univariate logistic regression analysis was first performed to identify which factors or predictors were associated with in-hospital mortality in all study patients and then only among the elderly patients. Predictors that showed a $\mathrm{p}$ value $\leq 0.20$ in the univariate analysis were entered into the multivariate analysis. A multivariate logistic regression analysis with a backward elimination procedure was undertaken to obtain an adjusted odds ratio (OR) along with 95\% confidence interval $(95 \% \mathrm{CI})$ and define which variables were independently associated with inhospital mortality between all study patients and then only among the elderly patients. Statistical tests were 2 -sided and $\mathrm{p}<0.05$ was considered statistically significant. Statistical analyses were performed using IBM $^{\mathrm{TM}}$ Statistical Package for the Social Science $\left(\right.$ SPSS $^{\mathrm{TM}}$ ) version 20.0 for Windows.

\section{RESULTS}

\section{Patients}

This analysis included 848 patients admitted to the ICU with severe sepsis or septic shock. Elderly patients accounted for $62.6 \%(531 / 848)$ of patients and nonelderly patients for $37.4 \%$ (317/848) of patients (Table 1 ). The median (IQR) age was, respectively, for elderly and nonelderly patients, 80 years (73-86) and 51 years (40-59), with $\mathrm{p}<0.001$.

Table 1. Baseline characteristics of study participants

\begin{tabular}{|c|c|c|c|}
\hline Characteristic & $\begin{array}{c}<65 \text { years } \\
317(37.4 \%) \\
n(\%)\end{array}$ & $\begin{array}{c}\geq 65 \text { years } \\
531(62.6 \%) \\
n(\%)\end{array}$ & p value \\
\hline Male sex & $178(56.2)$ & $310(58.4)$ & 0.566 \\
\hline \multicolumn{4}{|l|}{ Underlying disease } \\
\hline Systemic hypertension & $89(28.1)$ & $280(52.9)$ & $<0.001$ \\
\hline Diabetes mellitus & $69(21.8)$ & $173(32.7)$ & 0.001 \\
\hline Neoplasms & $73(23.0)$ & $146(27.6)$ & 0.142 \\
\hline Congestive heart failure & $12(3.8)$ & $73(13.8)$ & $<0.001$ \\
\hline Coronary insufficiency & $18(5.7)$ & $72(13.6)$ & $<0.001$ \\
\hline COPD & $7(2.2)$ & $67(12.7)$ & $<0.001$ \\
\hline Chronic renal failure & $10(3.2)$ & $44(8.3)$ & 0.003 \\
\hline Chronic renal failure RRT & $12(3.8)$ & $30(5.7)$ & 0.255 \\
\hline Liver cirrhosis & $60(18.9)$ & $20(3.8)$ & $<0.001$ \\
\hline Solid organ transplantation & $66(20.8)$ & $14(2.6)$ & $<0.001$ \\
\hline HIV & $3(0.9)$ & $1(0.2)$ & 0.151 \\
\hline Number of comorbid conditions & & & $<0.001$ \\
\hline 0 & $85(26.8)$ & $75(14.1)$ & \\
\hline 1 & $109(34.4)$ & $161(30.3)$ & \\
\hline 2 & $80(25.2)$ & $168(31.7)$ & \\
\hline$\geq 3$ & $43(13.6)$ & $127(23.9)$ & \\
\hline \multicolumn{4}{|l|}{ Source of infection } \\
\hline Respiratory tract & $144(45.4)$ & $307(57.8)$ & $<0.001$ \\
\hline Urinary tract & $51(16.1)$ & $85(16.0)$ & 1.000 \\
\hline Abdominal & $84(26.5)$ & $77(14.5)$ & $<0.001$ \\
\hline Skin and soft tissue & $9(2.8)$ & $25(4.7)$ & 0.208 \\
\hline Others & $12(3.8)$ & $20(3.8)$ & 1.000 \\
\hline Bloodstream & $13(4.1)$ & $10(1.9)$ & 0.078 \\
\hline Unknown & $4(1.3)$ & $7(1.3)$ & 1.000 \\
\hline \multicolumn{4}{|l|}{ Site of diagnosis, $n(\%)$} \\
\hline Emergency department & $155(48.9)$ & $270(50.8)$ & 0.619 \\
\hline Hospital floor & $107(33.8)$ & $104(19.6)$ & $<0.001$ \\
\hline Intermediary care & $18(5.7)$ & $93(17.5)$ & $<0.001$ \\
\hline Intensive care unit & $33(10.4)$ & $61(11.5)$ & 0.653 \\
\hline Other & $4(1.3)$ & $3(0.6)$ & 0.434 \\
\hline
\end{tabular}

Elderly patients were more likely to have systemic hypertension $(52.9 \%$ versus $28.1 \%$; $\mathrm{p}<0.001)$, diabetes ( $32.7 \%$ versus $21.8 \%$; $\mathrm{p}=0.001$ ), ischemic heart disease ( $13.6 \%$ versus $5.7 \%$; $\mathrm{p}<0.001$ ), congestive heart failure ( $13.8 \%$ versus $3.8 \% ; \mathrm{p}<0.001)$, chronic renal failure $(8.3 \%$ versus $3.2 \% ; \mathrm{p}=0.003)$ and chronic obstructive 
pulmonary disease $(12.7 \%$ versus $2.2 \%$; $\mathrm{p}<0.001)$ when compared to non-elderly patients. Solid organ transplantation $(20.8 \%$ versus $2.6 \%$; $\mathrm{p}<0.001)$ and liver cirrhosis $(18.9 \%$ versus $3.8 \%$; $<<0.001)$ were more frequent in non-elderly patients compared to elderly patients (Table 1 ).

The main source of infection in elderly and nonelderly patients was the respiratory tract $(57.8 \%$ versus $45.4 \%$, for elderly and non-elderly patients; $p<0.001$ ) while intra-abdominal infections were more common in non-elderly patients.

\section{Site of diagnosis}

The most common patient location at severe sepsis and septic shock diagnosis was the emergency department, with no difference between elderly and non-elderly patients $(50.8 \%$ versus $48.9 \%$; $\mathrm{p}=0.619)$ (Table 1$)$.

A large proportion of non-elderly patients were diagnosed on the hospital floor $(33.8 \%$ versus $19.6 \%$, for non-elderly and elderly patients; $\mathrm{p}<0.001$ ), while intermediary care was the most frequent site of diagnosis for elderly patients in comparison to nonelderly patients $(17.5 \%$ versus $5.7 \%$; $\mathrm{p}<0.001)$ (Table 1$)$.

\section{Clinical presentation}

The frequency of severe sepsis $(43.3 \%$ versus $44.5 \%$, for elderly and non-elderly patients; $\mathrm{p}=0.783$ ) and septic shock ( $56.7 \%$ versus $55.5 \%$, for elderly and nonelderly patients; $p=0.783$ ) did not differ between the groups (Table 2). Elderly patients had a higher median

Table 2. Clinical presentation of study patients

\begin{tabular}{|c|c|c|c|}
\hline Characteristic & $\begin{array}{c}<65 \text { years } \\
317(37.4 \%)\end{array}$ & $\begin{array}{c}\geq 65 \text { years } \\
531(62.6 \%)\end{array}$ & $\begin{array}{c}\mathbf{p} \\
\text { value }\end{array}$ \\
\hline APACHE II score, median [IQR] & $19[15-24]$ & $22[18-28]$ & $<0.001$ \\
\hline Arterial lactate (mmol/L), median [lOR] & $2.4[1.3-4.1]$ & $2.2[1.4-3.6]$ & 0.285 \\
\hline Severe sepsis, $n(\%)$ & $141(44.5)$ & $230(43.3)$ & 0.775 \\
\hline Septic shock, n (\%) & $176(55.5)$ & $301(56.7)$ & \\
\hline \multicolumn{4}{|l|}{ Clinical presentation, n (\%) } \\
\hline Hypotension & $229(72.2)$ & $384(72.3)$ & 1.000 \\
\hline Lactate $\geq 4.0 \mathrm{mmol} / \mathrm{L}$ & $86(27.7)$ & $101(19.7)$ & 0.008 \\
\hline Number of organ dysfunctions, median [IOR] & $2[2-4]$ & $3[2-3]$ & 0.829 \\
\hline \multicolumn{4}{|l|}{ Organ dysfunction, $\mathrm{n}(\%)$} \\
\hline Circulatory & $230(72.6)$ & $361(68.0)$ & 0.165 \\
\hline Respiratory & $181(57.1)$ & $325(61.2)$ & 0.248 \\
\hline Renal & $136(42.9)$ & 205 (38.6) & 0.220 \\
\hline CNS & $92(29.0)$ & $181(34.1)$ & 0.130 \\
\hline Hepatic & $19(6.0)$ & $17(3.2)$ & 0.055 \\
\hline Metabolic & $106(33.4)$ & 177 (33.3) & 1.000 \\
\hline Hematologic & $93(29.3)$ & $130(24.5)$ & 0.126 \\
\hline
\end{tabular}

(IQR) APACHE II score [22 (18-28) versus 19 (15-24); $\mathrm{p}<0.001$ ] compared to non-elderly patients, although the median number of new organ dysfunctions did not differ between the groups $(p=0.829)$.

\section{Administered treatments}

Compliance with the institutional protocol for severe sepsis and septic shock resuscitation has been published elsewhere. $^{(3)}$ The elderly patients received less fluid [median (IQR)] during the initial 6-hours of resuscitation than the non-elderly patients [1.8 (1.0 to 2.5$)$ versus 2.0 (1.4 to 3.0) liters, for elderly and non-elderly patients; $\mathrm{p}=0.001]$. The need for vasopressors $(58.8 \%$ versus 58.7 , for elderly and non-elderly patients; $\mathrm{p}=0.981$ ) and mechanical ventilation $(38.4 \%$ versus $38.2 \%$, for elderly and non-elderly patients; $\mathrm{p}=0.943$ ) did not differ between the groups.

\section{Outcomes}

In-hospital mortality and mortality at day 28 did not differ between elderly and non-elderly severe sepsis and septic shock patients (Table 3 ). The median (IQR) length of hospital stay was higher in elderly compared to non-elderly patients admitted with severe sepsis [15 (8-34) versus 12 (6-24) days; $p=0.027]$ or septic shock [21 (11-47) versus 18 (9-36) days; $\mathrm{p}=0.016]$. The median length of ICU stay did not differ between elderly and non-elderly severe sepsis and septic shock patients.

Table 3. Mortality rates and length of intensive care unit and hospital stay

\begin{tabular}{|c|c|c|c|}
\hline Outcomes & $\begin{array}{c}<65 \text { years } \\
317(37.4 \%)\end{array}$ & $\begin{array}{c}\geq 65 \text { years } \\
531(62.6 \%)\end{array}$ & $\begin{array}{c}\mathbf{p} \\
\text { value }\end{array}$ \\
\hline \multicolumn{4}{|l|}{ Severe sepsis } \\
\hline Mortality day $28, \mathrm{n}(\%)$ & $13 / 135(9.6)$ & $33 / 217(15.2)$ & 0.146 \\
\hline In-hospital mortality, n (\%) & 20/141 (14.2) & $47 / 230(20.4)$ & 0.164 \\
\hline Length of ICU stay (days), median [IQR] & $3[2-7]$ & $3[1-9]$ & 0.583 \\
\hline Length of hospital stay (days), median [IOR] & $12[6-24]$ & 15 [8-34] & 0.027 \\
\hline \multicolumn{4}{|l|}{ Septic shock } \\
\hline Mortality day $28, n^{0}(\%)$ & $63 / 166(38.0)$ & $101 / 290(34.8)$ & 0.543 \\
\hline In-hospital mortality, $\mathrm{n}^{0}(\%)$ & 70/176 (39.8) & 134/301(44.5) & 0.338 \\
\hline Length of ICU stay (days), median [IOR] & $5[2-12]$ & $6[3-13]$ & 0.146 \\
\hline Length of hospital stay (days), median [IOR] & $18[9-36]$ & $21[11-47]$ & 0.016 \\
\hline \multicolumn{4}{|l|}{ Severe sepsis and septic shock } \\
\hline Mortality day $28, \mathrm{n}(\%)$ & $76 / 301(25.2)$ & $134 / 507(26.4)$ & 0.740 \\
\hline In-hospital mortality, n (\%) & $90 / 317(28.4)$ & $181 / 531(34.1)$ & 0.094 \\
\hline Length of ICU stay (days), median [IQR] & $4[2-10]$ & $5[2-11]$ & 0.141 \\
\hline Length of hospital stay (days), median [IOR] & 14 [8-29] & $18[10-41]$ & 0.001 \\
\hline
\end{tabular}

\section{Predictors of death}

The univariate and multivariate logistic regression analysis addressing the predictors of death in all septic 
patients and only among the elderly patients are presented in tables 4 and 5, respectively.

Table 4. Univariate and multivariate logistic regression analysis addressing the main risk factors for in-hospital mortality including 848 severe sepsis and septic shock patients

\begin{tabular}{|c|c|c|c|c|c|c|}
\hline \multirow[b]{2}{*}{ Characteristics } & \multicolumn{3}{|c|}{ Univariate analysis } & \multicolumn{3}{|c|}{ Multivariate analysis } \\
\hline & OR & $95 \% \mathrm{Cl}$ & $\begin{array}{c}\mathbf{p} \\
\text { value }\end{array}$ & OR & $95 \% \mathrm{Cl}$ & $\begin{array}{c}p \\
\text { value }\end{array}$ \\
\hline Male sex & 0.82 & $0.61-1.10$ & 0.182 & 0.68 & $0.48-0.97$ & 0.032 \\
\hline \multicolumn{7}{|l|}{ Site of diagnosis } \\
\hline Emergency department & 1.00 & & & & & \\
\hline Hospital floor & 3.10 & $2.14-4.48$ & $<0.001$ & 2.74 & $1.78-4.22$ & $<0.001$ \\
\hline Intermediary care & 4.93 & $3.15-7.71$ & $<0.001$ & 4.39 & $2.63-7.35$ & $<0.001$ \\
\hline Intensive care unit & 5.78 & $3.59-9.31$ & $<0.001$ & 3.64 & $2.04-6.50$ & $<0.001$ \\
\hline Liver cirrhosis & 2.62 & $1.65-4.18$ & $<0.001$ & 2.13 & $1.22-3.72$ & 0.008 \\
\hline Urinary tract infection & 0.30 & $0.18-0.49$ & $<0.001$ & 0.40 & $0.21-0.75$ & 0.040 \\
\hline APACHE I| score & 1.11 & $1.08-1.13$ & $<0.001$ & 1.08 & $1.05-1.11$ & $<0.001$ \\
\hline Arterial lactate & 1.18 & $1.12-1.25$ & $<0.001$ & 1.14 & $1.06-1.22$ & $<0.001$ \\
\hline Number of organ dysfunction & 1.56 & $1.38-1.76$ & $<0.001$ & 1.21 & $1.04-1.40$ & 0.012 \\
\hline Mechanical ventilation & 4.94 & $3.62-6.73$ & $<0.001$ & 1.89 & $1.29-2.78$ & 0.001 \\
\hline
\end{tabular}

APACHE II: Acute Physiology and Chronic Health Evaluation II (the score can range from zero to 71, with higher scores indicating more severe illness). OR: odds ratio; 95\% Cl: 95\% confidence interval.

Table 5. Univariate and multivariate logistic regression analysis addressing the main risk factors for in-hospital mortality among the 531 elderly ( $\geq 65$ years) patients

\begin{tabular}{|c|c|c|c|c|c|c|}
\hline \multirow[b]{2}{*}{ Characteristics } & \multicolumn{3}{|c|}{ Univariate analysis } & \multicolumn{3}{|c|}{ Multivariate analysis } \\
\hline & $\mathbf{O R}$ & $95 \% \mathrm{Cl}$ & $\begin{array}{c}\mathbf{p} \\
\text { value }\end{array}$ & $\mathbf{O R}$ & $95 \% \mathrm{Cl}$ & $\begin{array}{c}\mathbf{p} \\
\text { value }\end{array}$ \\
\hline Age, years & 1.04 & $1.02-1.07$ & $<0.001$ & 1.04 & $1.01-1.07$ & 0.003 \\
\hline Male sex & 0.69 & $0.48-1.00$ & 0.048 & 0.61 & $0.40-0.94$ & 0.023 \\
\hline \multicolumn{7}{|l|}{ Site of diagnosis } \\
\hline Emergency department & 1.00 & & & & & \\
\hline Hospital floor & 2.71 & $1.67-4.39$ & $<0.001$ & 2.40 & $1.37-4.20$ & 0.002 \\
\hline Intermediary care & 3.82 & $2.31-6.30$ & $<0.001$ & 3.71 & $2.07-6.65$ & $<0.001$ \\
\hline Intensive care unit & 4.12 & $2.31-7.37$ & $<0.001$ & 3.07 & $1.52-6.20$ & 0.002 \\
\hline Systemic hypertension & 0.63 & $0.44-0.90$ & 0.012 & 0.56 & $0.36-0.86$ & 0.009 \\
\hline Diabetes mellitus & 0.58 & $0.39-0.87$ & 0.008 & 0.58 & $0.36-0.94$ & 0.025 \\
\hline Abdominal infection & 0.69 & $0.40-1.18$ & 0.174 & 0.50 & $0.27-0.95$ & 0.034 \\
\hline APACHE II score & 1.09 & $1.06-1.12$ & $<0.001$ & 1.06 & $1.03-1.10$ & $<0.001$ \\
\hline Mechanical ventilation & 5.11 & $3.47-7.52$ & $<0.001$ & 2.18 & $1.36-3.52$ & 0.001 \\
\hline Vasopressor administration & 3.25 & $2.17-4.85$ & $<0.001$ & 1.98 & $1.24-3.18$ & 0.005 \\
\hline
\end{tabular}

The site of diagnosis, the presence of liver cirrhosis, APACHE II score, the arterial blood lactate level, the number of organ dysfunction and the need for mechanical ventilation were independently associated with increased risk of in-hospital death among severe sepsis and septic shock patients. Increased age, the site of diagnosis, APACHE II score, the need for mechanical ventilation and vasopressor administration were independently associated with increased risk of inhospital death among elderly patients.

\section{DISCUSSION}

This study demonstrated that in-hospital and 28-day mortality rates were not different between elderly and non-elderly patients submitted to early goal-directed therapy for the treatment of severe sepsis and septic shock. However, increased age was an independent predictor of in-hospital death among elderly patients. Therapeutic goals included in the first 6 hours of resuscitation from the initial diagnosis of severe sepsis and septic shock were achieved similarly in both groups. Nevertheless, less fluid for hemodynamic stabilization was administered to the elderly patients.

Traditionally, elderly patients receive less intensive treatment compared to non-elderly patients, probably due to the possibility of deleterious effects of an aggressive therapy and fear of fluid overload. ${ }^{(16)}$ Recently, increased acceptance of complex ICU interventions in older patients was associated with greater intensity of treatment and improved survival. ${ }^{(10)}$ This is perhaps the result of increased experience with the care of elderly patients over the years and technical improvements such as protocols associated with hemodynamic monitoring tools and continuous renal replacement therapy, representing a true evolution in practice throughout the times. Our results confirm these findings, as the proportion of elderly patients receiving mechanical ventilation and vasopressors was not different from that in younger patients.

Our findings confirm the tolerance of elderly patients to an early goal-directed therapy algorithm for severe sepsis and septic shock resuscitation, with no differences in mortality compared to non-elderly patients. These results have important clinical implications, since there is an increasing demand for ICU admission of elderly patients, which is often associated with high costs and limited availability of ICU beds worldwide..$^{(7,17,18)}$ Our results support the concept that ICU admission and early goal-directed therapy implementation should not be denied to elderly patients showing severe sepsis and septic shock.

The impact of age itself on higher mortality rates due to sepsis is not uniformly observed in epidemiological investigations. ${ }^{(11,19,20)}$ Other retrospective analysis demonstrated that age was associated with a significantly increased risk of death in elderly patients with severe sepsis or septic shock. ${ }^{(11,18)}$ Nonetheless, these studies rely on administrative databases for sepsis diagnosis, which may be inaccurate and lacking important aspects such as adherence to the proposed treatment. Similarly, in our study, after adjustments for baseline patient's characteristics in a multivariable logistic regression 
model, age was independently associated with increased risk of in-hospital mortality in elderly patients with severe sepsis or septic shock.

Most studies addressing mortality in septic patients have focused on short-term endpoints. ${ }^{(4,12)}$ Few observational studies have addressed the long-term prognosis of elderly severe sepsis and septic shock patients submitted to early goal-directed therapy. Lemay et al. reported a 1-year mortality rate of $31 \%$ in elderly patients with severe sepsis. ${ }^{(20)}$ Nevertheless, adherence to specific therapeutic goals besides antibiotics administration was not reported and the study relied on administrative database for sepsis diagnosis. Similarly, Wang et al. described a 1-year mortality rate of $23 \%$ in a population of adults aged 45 or older, with sepsis defined as hospitalization or treatment in the emergency department for a serious infection with the presence of two or more systemic inflammatory response criteria, with no mention of ICU patients with severe sepsis or septic shock. ${ }^{(21)}$ Recently, it was shown that long-term survival in elderly patients with circulatory failure (including sepsis) is poor, with mortality rates of 92 and $97 \%$ after 6 and 12 months, respectively. ${ }^{(13)}$ These findings support the hypothesis that excess longterm mortality persists among those suffering from sepsis, probably because sepsis triggers an independent pathophysiological process leading to early death.

Respiratory infections accounted for the most sepsis cases in elderly patients, whereas abdominal infections were the most common cause in younger patients, a finding which has not been confirmed by other authors, where respiratory infection was the major source of infection in both elderly and non-elderly patients. ${ }^{(11)}$ A possible explanation for this interesting finding is the greater incidence of liver cirrhosis and solid organ transplantation in younger patients, probably reflecting a high proportion of patients with spontaneous bacterial peritonitis.

Our study has limitations. First, we were unable to evaluate the functional status before and after ICU discharge. Functional status has been related to pre-existing underlying factors, and it plays a greater role than chronological age in the outcome of elderly patients with severe sepsis and septic shock. ${ }^{(22)}$ Second, this was a single center and retrospective study, which potentially limits the generalizability of our findings. Lastly, we used 65 as the cut-off age following the definition of elderly by World Health Organization. However, as pointed out earlier, the chronological age is not always representative of the functional condition of the patients.

\section{CONCLUSION}

In this study population of severe sepsis and septic shock patients, early resuscitation of elderly patients was not associated with increase in mortality. Elderly patients with severe sepsis or septic shock may benefit from aggressive resuscitation and advanced treatment modalities. However, prospective studies are warranted to address long-term impact of resuscitation maneuvers on functional status and quality of life.

\section{ACKNOWLEDGEMENTS}

We thank Débora Raquel de Melo for her assistance during the data acquisition and to Helena Spalic for proof-reading this manuscript.

\section{REFERENCES}

1. Vincent JL, Marshall JC, Namendys-Silva SA, François B, Martin-Loeches I, Lipman J, Reinhart K, Antonelli M, Pickkers P, Njimi H, Jimenez E, Sakr Y; ICON investigators. Assessment of the worldwide burden of critical illness: the intensive care over nations (ICON) audit. Lancet Respir Med. 2014;2(5):380-6.

2. Angus DC, Linde-Zwirble WT, Lidicker J, Clermont G, Carcillo J, Pinsky MR Epidemiology of severe sepsis in the United States: analysis of incidence, outcome, and associated costs of care. Crit Care Med. 2001;29(7):1303-10.

3. Silva E, Pedro Mde A, Sogayar AC, Mohovic T, Silva CL, Janiszewski M, Cal RG, de Sousa EF, Abe TP, de Andrade J, de Matos JD, Rezende E, Assunção M, Avezum A, Rocha PC, de Matos GF, Bento AM, Corrêa AD, Vieira PC, Knobel E; Brazilian Sepsis Epideiological Study. Brazilian Sepsis Epidemiological Study (BASES study). Crit Care. 2004;8(4):R251-60.

4. Rivers E, Nguyen B, Havstad S, Ressler J, Muzzin A, Knoblich B, Peterson E Tomlanovich M; Early Goal-Directed Therapy Collaborative Group. Early goaldirected therapy in the treatment of severe sepsis and septic shock. N Engl J Med. 2001;345(19):1368-77.

5. Dellinger RP, Levy MM, Rhodes A, Annane D, Gerlach H, Opal SM, Servransky JE, Sprung CL, Douglas IS, Jaeschke R, Osborn TM, Nunnally ME, Townseend SR, Reinhart K, Kleinpell RM, Angus DC, Deutschman CS, Machado FR, Rubenfeld GD, Webb SA, Beale RJ, Vincent JL, Moreno R; Surviving Sepsis Campaingn Guidelines Committee including the Pediatric Subgroup. Surviving sepsis campaign: international guidelines for management of severe sepsis and septic shock: 2012. Crit Care Med. 2013;41(2):580-637.

6. Angus DC, van der Poll T. Severe sepsis and septic shock. N Engl J Med. 2013;369(9):840-51. Review. Erratum in: N Engl J Med. 2013;21;369(21):2069

7. Bagshaw SM, Webb SA, Delaney A, George C, Pilcher D, Hart GK, et al. Very old patients admitted to intensive care in Australia and New Zealand: a multicentre cohort analysis. Crit Care. 2009;13(2):R45.

8. Yang Y, Yang KS, Hsann YM, Lim V, Ong BC. The effect of comorbidity and age on hospital mortality and length of stay in patients with sepsis. J Crit Care. 2010;25(3):398-405.

9. Koller K, Rockwood K. Frailty in older adults: implications for end-of-life care. Cleve Clin J Med. 2013;80(3):168-74. Review.

10. Lerolle N, Trinquart L, Bornstain C, Tadié JM, Imbert A, Diehl JL, et al. Increased intensity of treatment and decreased mortality in elderly patients in an intensive care unit over a decade. Crit Care Med. 2010;38(1):59-64.

11. Martin GS, Mannino DM, Moss M. The effect of age on the development and outcome of adult sepsis. Crit Care Med. 2006;34(1):15-21.

12. Nasa $P$, Juneja $D$, Singh 0 , Dang $R$, Arora V. Severe sepsis and its impact on outcome in elderly and very elderly patients admitted in intensive care unit. J Intensive Care Med. 2012;27(3):179-83. 
13. Biston P, Aldecoa C, Devriendt J, Madl C, Chochrad D, Vincent JL, et al. Outcome of elderly patients with circulatory failure. Intensive Care Med. 2014; 40(1):50-6.

14. Bone RC, Balk RA, Cerra FB, Dellinger RP, Fein AM, Knaus WA, et al. Definitions for sepsis and organ failure and guidelines for the use of innovative therapies in sepsis. The ACCP/SCCM Consensus Conference Committee. American College of Chest Physicians/Society of Critical Care Medicine. Chest. 1992;101(6): 1644-55. Review.

15. Knaus WA, Draper EA, Wagner DP, Zimmerman JE. APACHE II: a severity of disease classification system. Crit Care Med. 1985;13(10):818-29.

16. Boumendil A, Aegerter P, Guidet B. CUB-Rea Network. Treatment intensity and outcome of patients aged 80 and older in intensive care units: a multicenter matched-cohort study. J Am Geriatr Soc. 2005;53(1):88-93.

17. Wunsch $H$, Angus DC, Harrison DA, Collange 0 , Fowler $R$, Hoste EA, et al. Variation in critical care services across North America and Western Europe. Crit Care Med. 2008;36(10):2787-93, el-9. Review.
18. Blot S, Cankurtaran M, Petrovic M, Vandijck D, Lizy C, Decruyenaere J, et al. Epidemiology and outcome of nosocomial bloodstream infection in elderly critically ill patients: a comparison between middle-aged, old, and very old patients. Crit Care Med. 2009;37(5):1634-41.

19. Garnacho-Montero J, Garcia-Garmendia JL, Barrero-Almodovar A, JimenezJimenez FJ, Perez-Paredes C, Ortiz-Leyba C. Impact of adequate empirical antibiotic therapy on the outcome of patients admitted to the intensive care unit with sepsis. Crit Care Med. 2003;31(12):2742-51.

20. Lemay AC, Anzueto A, Restrepo Ml, Mortensen EM. Predictors of long-term mortality after severe sepsis in the elderly. Am J Med Sci. 2014;347(4):282-8.

21. Wang HE, Szychowski JM, Griffin R, Safford MM, Shapiro NI, Howard G. Longterm mortality after community-acquired sepsis: a longitudinal populationbased cohort study. BMJ Open. 2014;4(1):e004283.

22. McDermid RC, Stelfox HT, Bagshaw SM. Frailty in the critically ill: a novel concept. Crit Care. 2011;15(1):301. Review. 